\title{
Hayat-Dışı Sigorta Şirketlerinde 16 Yıl Arayla Yapılan Etkinlik Analizleri ve Sonuçlarının Karşılaştırılması ${ }^{1}$
}

\author{
Deniz ÇAKMAK ${ }^{2}$ \& Feride HAYIRSEVER BAŞTÜRK ${ }^{3}$
}

\section{Özet}

Etkinlik en az maliyet ve çabayla en yüksek çıktıya ulaşabilme sürecidir ve yoğun rekabet koşulları içinde bulunan sigortacılık sektöründe de etkinlik analizleri yapılmaktadır. Bu çalışmada Türk Sigorta Sektöründe hayat dışı branşlarda faaliyet gösteren sigorta şirketlerinin 2002 ve 2018 yıllarındaki benzer girdi ve çıktılar kullanılarak yapılan veri zarflama analizi etkinlik skorları karşılaştırılmıştır. 2002 yılında hayat dışı alanda faaliyet gösteren şirketlerden sadece 7'sinde herhangi bir değiş̧iklik olmamış diğerlerinde ise, isim veya ortak değişikliği, iflas ve TMSF'ye devirler söz konusu olmuştur. Sigortalı olarak hayat dışı branşlarda 16 yıl boyunca poliçeleri aynı şirketle yaptırabilme olasıllığı oldukça düşüktür. 2018 y1lında analize dahil edilen 37 sigorta şirketinin etkin olanlarının sayısı 7'de kalmıştır. Bu sonuçlara göre, sektör pazar payının büyük çoğunluğunu elinde bulunduran görece daha büyük ölçeğe sahip olan sigorta şirketleri, kendinden daha küçük ölçekte hizmet sunan sigorta şirketlerine göre etkinsiz olarak gözlenmiştir. İncelenen 2013-2018 döneminde, en düşük etkinlik skorları 2016 yılında yaşanmış, 2017 yılında yükselmesine rağmen 2018 yılında tekrar etkinlik düşüşleri görülmüştür. Genelde Türk Sigorta Sektörü özelde ise, hayat-dışı branşlarda bulunan sigorta şirketleri için etkinlik skorlarındaki değişimin önemi vurgulanmıştır.

Anahtar Kelimeler: Türk Sigorta Sektörü, Hayat-Dışı Şirketler, Etkinlik Analizi, Veri Zarflama Analizi

\section{Efficiency Analysis Performed 16 Years Apart in Non-life Insurance Companies and Comparison of Results}

\begin{abstract}
Efficiency is the process of achieving the highest output with minimum cost and effort, and efficiency analysis have been made in the insurance industry which is in highly competitive circumstances. In this study, efficiency scores of data envelopment analysis of the insurance companies operating in non-life branches in Turkish Insurance Industry, which were formed to be used similar inputs and outputs in 2002 and 2018 were compared. In 2002, only 7 of the non-life companies did not make any changes; in others, change of name or joint of companies, bankruptcy, and transfers to the SDIF are a matter of discussion. It is very unlikely that the insured will be able to issue a policy with the same company in non-life branches for 16 years. The number of efficient ones of 37 insurance companies which were included in the analysis in 2018 remained at 7. According to these results, the insurance companies which hold the majority of the market share in the industry and have a relatively large scale, have been observed to be ineffective than the insurance companies which provide services at a smaller scale. In 2013-2018 periods, the lowest efficiency scores were experienced in 2016, and despite the increase in 2017 , there was a decrease in efficiency again in 2018. The importance of the change in efficiency scores for insurance companies in insurance industry in general and in non-life branches in particular was emphasized.
\end{abstract}

Keywords: Turkish Insurance Industry, Non-Life Companies, Efficiency Analysis, Data Envelopment Analysis

\footnotetext{
${ }^{1}$ Bilecik Şeyh Edebali Üniversitesi, Sosyal Bilimler Enstitüsü, Bankacılık ve Finans Anabilim Dalı, Türk Sigortacılık Sektörünün Etkinlik Analizi ve Ekonomik Büyümeye Etkisi isimli yüksek lisans tezinden üretilmiştir. "II. Business\&Organization Research Conference 4-6 Eylül 2019, İzmir"de sözlü bildiri olarak sunulmuștur.

${ }^{2}$ Yüksek lisans ögrrencisi, Bỉlecik Şeyh Edebali Üniversitesi, Sosyal Bilimler Enstitüsü, Bankacılık ve Finans Anabilim Dalı, denizcakmak_@hotmail.com

${ }^{3}$ Doç. Dr., Bilecik Şeyh Edebali Üniversitesi, Uygulamalı Bilimler Fakültesi, Bankacılık ve Finans Bölümü, feride.basturk@bilecik.edu.tr
} 


\section{Giriş}

Performans ölçümünün amacı, yapılan iş ve yürütülen faaliyetteki etkinliği artırmaktır(Thanassoulis 2003:1). Etkinlik kıyaslama yoluyla birden çok sayıdaki şirketin performansının değerlendirilmesidir (Atan 2005: 11-12). Etkinlik, en az maliyet ve çabayla elde edilebilecek en yüksek skoru yapma kapasitesi olarak tanımlanabilir. Şirketler için etkinlik ise, geliştirilen bir girdi ve çıktı sistemiyle amaçlanan işlerin en iyi biçimde gerçekleştirilmesi olarak açıklanmaktadır(Yücel 2017:9). Pareto'ya göre, herhangi bir girdi veya çıktının her biri diğer girdilerin veya çıktıların kötüleşmesine gerek kalmadan geliştiriliyorsa, tüm birimler için etkinlik sağlanmış denilmektedir(Cooper, Seiford ve Tone 2007:3).

Şirketler, performans değerlendirmesi yapmak yoluyla, kendilerinin ve rakiplerinin kuvvetli ve zayıf taraflarını belirleyebilmektedirler. Zayıf olarak belirledikleri alanlarda düzeltmeleri zamanında yapabilirlerse, yoğun rekabetin yaşandığı pazar koşullarında daha sağlam bir şekilde yol alabilirler ve başarı seviyelerini yükseltme olanağı bulabilirler. Bunu gerçekleştiremeyen şirketlerin ise uzun dönemde başarılı olması oldukça zordur(Kılıçkaplan ve Baştürk 2004: 64).

Etkinlik en az maliyet ve çabayla en yüksek çıtıya ulaşabilme sürecidir ve şirketlerin kaynaklarını etkin kullanmaları ve sektördeki yerlerini görebilmeleri açısından son derece önemlidir. Finansal sistemin bir parçası olan ve yoğun rekabet koşulları içinde bulunan sigortacılık sektöründe de etkinlik analizleri yapılarak, şirketlerin performanslarını değerlendirmeleri beklenmektedir. Etkinlik analizinde parametrik olmayan yöntemlerden veri zarflama analizi sıklıkla kullanılmıştır. Ülkemizde 2000'li yıllarda, bu amaçla çalışmalar yapılmaya başlanmış, ilerleyen yıllarda ve günümüzde de bunu artan sayıda araştırma ve tez çalışması takip etmiştir.

$\mathrm{Bu}$ araştırmada da farklı bir bakış açısı ile, Türk Sigorta Sektöründe prim üretiminde \%82'lik paya sahip olan hayat-dışı branşlarda faaliyet gösteren sigorta şirketlerinin etkinliğini analiz etmek amaçlanmıştır. Araştırmacılar ve yakın zamanda yayınlanan 2018 verilerini de dikkate alarak bu çalışmayı oluşturmuşlardır.

Türk Sigorta Sektöründe hayat dışı branşlarda faaliyet gösteren sigorta şirketlerinin 2002 ve 2018 yıllarındaki benzer girdi ve çıktılar kullanılarak yapılan veri zarflama analizi etkinlik skorları karşılaştırılmıştır. Bu kapsamda çalışma sürecinde 2002 yılında yapılan bir araştırmadan (Kılıçkaplan ve Baştürk, 2004) ve 2013-2017 yıllarını kapsayan tez (Çakmak, 2019), çalışmasından destek alınmıştır. Ayrıca ilgili yıllar kapsamında etkinlik artış ve azalışları incelenmiş ve hayat dışı branşlar açısından etkinlik skorlarındaki değişimlere dikkat çekilmek istenmiştir. 


\section{Literatür Taraması}

Literatürde, sigorta sektörünün ve sigorta şirketlerinin etkinliklerini inceleyen pek çok çalışma mevcuttur. Cummins ve Weiss (1993) de, Amerika'da sorumluluk sigortası alanında çalışan sigorta şirketlerinin maliyet etkinlikleri belirlenmiştir. Çalışma 1980 ile 1988 arasındaki dönemi içermekte ve sigorta şirketleri ölçeklerine göre küçük/orta ve büyük olmak üzere ikiye ayrılmaktadır. Çalışma sonucuna göre, büyük ölçekte hizmet veren sigorta şirketlerinin maliyetleri ve etkinlikleri ilişkili bulunmuştur. Yine küçük ve orta ölçekteki sigorta şirketlerinin maliyetleri ve etkinlikleri arasında yüksek düzeyde ancak büyük ölçekli sigorta şirketlerine göre daha az oranda bir ilişki saptanmıştır.

Liu (1994), Tayvan sigorta sektöründe hayat branşında yer alan şirketlerin etkinliklerini ölçmeye çalışmıştır. Cummins ve Zi (1996), ABD'de hayat branşında yer alan sigorta şirketlerinin 1988 ve 1992 yılları arasındaki etkinlik düzeylerini farklı ekonometrik yöntemler dahilinde ölçmeye çalışmışlardır. Farklı ekonometrik yöntemler kullanılarak belirlenen etkinlik skorları birbirinden farklı olabilmektedir. Kullanılan yöntemler etkinlik düzeylerinin belirlenmesinde önemli bir faktördür.

Rai (1996) çalışmasında, 11 ülkede 106 sigorta şirketinin 1988-1992 yılları arasındaki etkinliğini ölçmüştür. Çalışmanın sonucuna göre, etkinlik ölçek büyüklüğüne ve ülkeye göre değişirken aynı zamanda uzmanlaşmaya göre de değişmektedir. Araştırma neticesinde, küçük ölçekteki sigorta şirketlerinin maliyet etkinliği büyük ölçekteki sigorta şirketlerinden daha yüksek olduğu gözlenmiştir. Yine uzmanlaşmış sigorta şirketlerinin diğer sigorta şirketlerine oranla daha etkin olduğu belirtilmiştir.

Jametti ve Ungern (2003) yaptıkları çalışmada, İsviçre'deki devlete ait ve özel sigorta şirketlerinin etkinlikleri araştırmıştır. Çalışma sonucunda, devlete ait olan sigorta şirketlerinin özel sigorta şirketlerinden daha etkin çalıştığı gözlenmiştir. Cummins, Rubio-Misas ve Zi (2004) de, İspanya'daki sigorta şirketlerinin 1989 ile 1997 yılları arasındaki yapısal ve teknik etkinlik düzeyleri ölçülmeye çalışılmıştır. Çalışmanın sonucuna göre, yapısal ve teknik etkinlik skorları arasında tutarlılık gözlenmiştir.

Barros, Barrossa ve Borges (2005), 1995 ve 2001 yılları arasında Portekiz'deki 27 sigorta şirketinin etkinlik analizi Malmquist Toplam Faktör Verimliliği yöntemi ile yapılmıştır. Çalışmada etkinlik değişimi ve teknolojik değişim öğrenilmeye çalışılmıştır. Araştırma sonucunda etkin bulunmayan sigorta şirketlerine kendilerini geliştirmesi gereken noktalar sunulmuştur.

Eling ve Luhnen (2008), 36 ülkede faaliyet gösteren sigorta şirketleriyle ilgili çalışma yapmışlardır. Şirketlerin ölçek büyüklükleri ve yapısal durumlarından bağımsız olarak teknik anlamdaki etkinliklerine bakılmıştır. Çalışma 2002 ve 2006 yılları arasındaki dönemi kapsamaktadır. Çalışmanın sonunda, araştırmada farklı yöntemler kullanılsa da etkinlik düzeylerinde büyük değişiklikler gözlenmemiştir. Lin ve Lee (2010) tarafından ortaya konan çalışmada, Tayvan'da faaliyet gösteren hayat şirketlerinin etkinlik analizi yapılmıştır. Çalışmada 2005 ve 2009 yılları arasındaki döneme ait 
veriler kullanılmıştır. Çalışmanın sonunda, hayat branşında faaliyette bulunan sigorta şirketlerinin teknik etkinliği düşük bulunmuştur.

Türkiye özelinde de, sigorta şirketlerinin etkinlik analizlerini konu edinen çalışmalara rastlamak mümkündür. Kılıçkaplan ve Baştürk (2004) tarafından yapılan çalışmada, Türkiye'de 2002 yılında hayat dışı branşlarda faaliyet gösteren 30 sigorta şirketinin etkinlik analizi gerçekleştirilmiştir. Girdiler belirlenirken reel finansal hizmetler ve finansal aracılık işlevi; çıktılar belirlenirken katma değer yaklaşımı gözetilmiştir. Çalışmanın sonucuna göre 13 sigorta şirketi etkin olarak bulunmuştur.

Kılıçkaplan ve Karpat (2004), 1998 ve 2002 yılları arasındaki dönemde hayat branşında faaliyette bulunan şirketlerin teknik, saf ve ölçek etkinliğini araştırmışlardır. Çalışmada personel sayısı ve yönetim giderleri, sabit varlıklar ve özsermaye girdi; alınan primler, teknik kar/zarar ve mali kar/zarar çıktı olarak alınmıştır. Araştırmaya konu olan yıllarda, sigorta şirketlerinin etkinliği düşmüştür. Çalışmada bunun sebebi, yaşanan krizin etkisiyle sigorta şirketlerinin bozulan özsermaye yapısı olarak belirtilmiştir.

Kayalı (2007) de, 2000-2006 yılları arasında Türkiye'de faaliyet gösteren sigorta şirketlerinin teknik, saf ve ölçek etkinliklerini ölçmüş ve bu etkinliklerdeki gelişimi belirtilen zaman aralığında incelemiştir. Etkinliklerin yıllar içindeki değişimi incelendiğinden Malmquist Toplam Faktör Verimliliği yöntemi kullanılmıştır. Yine, bu yönteme göre, 2000 ve 2006 yılları arasında Türkiye'de faaliyette bulunan sigorta şirketlerinin etkinlik değerlerinde yükseliş gözlenmiştir. Çalışmanın sonunda, teknik etkinsizliklerin sebebi, ölçek etkinsizliği olarak yorumlanmıştır. Çalışmaya göre, çıktı olarak belirlenen prim üretimi, optimum girdi bileşimiyle gerçekleşmemektedir.

Özbek (2007), 2004 yılında hayat ve hayat dışı branşlarda faaliyet gösteren toplam 44 sigorta şirketinin etkinliklerini incelemiştir. Girdi yönelimli yaklaşımı kullandığı çalışmasında hem ölçeğe göre sabit getiri hem de değişken getiri altında etkinliği ölçmüştür. Çalışmanın sonucunda, teknik anlamda kar eden şirketlerin etkin olamayabileceği görülmüştür.,

Kırer (2007), 2006 yılında Türkiye'de hayat dışı branşta faaliyet gösteren 24 sigorta şirketinin etkinlik analizlerini gerçekleştirmiştir. Çalışmanın sunucunda, 5 sigorta şirketi CCR modele göre etkinken; 14 sigorta şirketi BCC modelde etkin olarak bulunmuştur. Yine, hayat dışı branşta faaliyet gösteren 5 sigorta şirketi ölçeğe göre tam etkindir. Kılınç (2009) çalışmasında, 2004 ve 2007 yılları arasında hayat ve hayat dışı branşlarda işlem yapan toplam 37 şirketin etkinlik seyirlerine yer vermiştir. Çalışmanın sonuncunda, etkinsiz olarak bulunan birimlerin geleceğe dönük idari kararlarında girdi ve çıktı bileşimini gözden geçirmesi gerektiği vurgulanmıştır.

Altan (2010), 2005, 2006 ve 2007 yıllarında hayat dışı branşlarda faaliyette bulunana 25 sigorta şirketinin etkinliğini analiz etmiştir. Çalışmanın sonucunda sigorta şirketlerinin büyük çoğunluğu etkin bulunmamış ve yönetsel kararlarda girdi ve çıktı bileşiminin kontrol edilmesi tavsiye edilmiştir. Özcan (2011), 2002 ve 2009 yılları arasında hayat dışı branşlarda işlem yapan sigorta şirketlerinin etkinlik 
analizini yapmıştır. Çalışmanın sonucuna göre, sektörün en önemli sorunu etkinliği sağlayamamaktır. 2003, 2005 ve 2006 yıllarında sektör etkin bir çalışma gösterememiştir.

Horasan (2013), 2010 yılında hayat dışı branşlarda faaliyet göteren 32 sigorta şirketinin CCR ve BCC modelde etkinlik analizlerini gerçekleştirmiştir. Çalışmanın sonucunda, 18 sigorta şirketi CCR modelde etkin olarak bulunurken; 21 sigorta şirketi BBC modelde etkin olarak belirlenmiştir. Yaşanan etkinsizlik, \%10 oranında uygun ölçekte çalışılmamasından kaynaklanırken, \%90 oranında yönetimsel anlamdaki yetersizliklerden kaynaklanmaktadır.

Ayhan (2017), 2010 ve 2015 yılları arasında Türkiye'deki sigorta şirketlerinin etkinlik analizini yapmıştır. Analiz kapsamında hayat branşında faaliyet gösteren 10; hayat dışı branşta faaliyet gösteren 22 sigorta şirketini araştırmıştır. Çalışmada hayat dışı branşta işlem yapan sigorta şirketlerinin çoğu etkinsiz bulunurken, ortalama etkinliğin hayat branşında, hayat dışı branşa oranla daha yüksek olduğu gözlenmiştir. Çalışmanın sonucunda, Türkiye'deki sigorta şirketlerinin etkinlik skorları Avrupa'daki bazı ülkelere göre daha yükssek bulunmuştur. Ancak, Türkiye kişi başına düşen prim üretiminde Avrupa ülkelerinin gerisinde kalmıştır.

Tezergil (2018), 2014, 2015 ve 2016 yıllarında hayat dışı branşlarda hizmet veren sigorta şirketlerinin etkinliklerini ölçmektedir. Çalışmanın sonucunda, 2014 yılında 12, 2015 yılında 13 ve 2016 yılında ise 5 sigorta şirketi etkin olarak gözlenmiştir. 2016 yılında etkin şirket sayısının düşmesi, trafik sigortalarında yaşanan gelişmelerin şirketleri olumsuz etkilemesine bağlanmıştır.

\section{Araştırmanın Yöntemi ve Kapsamı}

\subsection{Araştırmanın Amacı}

Türk Sigorta Sektörü'nde etkinlik hesaplamalarının 2000'li yıllardan sonra daha yoğun olarak ele alındığı gözlemlenmiştir. Öncelikle bankacılık sektöründe başlayan çalışmalar sigortacılık sektörüne ve sigorta şirketlerine de uyarlanmıştır. İlerleyen zaman içinde çalışmaların sayısı ve kapsamı genişlemiştir. Araştırmacılar 2002 yılında yapılan bir araştırmadan (Kılıçkaplan ve Baştürk, 2004) yola çıkarak, 2013-2017 yıllarını kapsayan tez (Çakmak, 2019), çalışmasından destek alarak ve yakın zamanda yayınlanan 2018 verilerini de dikkate alarak bu çalışmayı oluşturmuşlardır.

$\mathrm{Bu}$ çalışmada; Türk Sigorta Sektöründe hayat dışı branşlarda faaliyet gösteren sigorta şirketlerinin 2002 ve 2018 y1llarındaki benzer girdi ve çıktılar kullanılarak yapılan veri zarflama analizi sonucunda bulunan etkinlik skorları karşılaştırılmıştır. Yaklaşık 16 yıllık bir zaman diliminde hayat dışı branşlarda faaliyet gösteren sigorta şirketlerindeki değişimle birlikte, temel göstergelerde sektörün genelinde görülen değişimlere ait bulguların gözlemlenmesi amaçlanmıştır. Ayrıca 2013-2018 dönemine ait ortalama etkinlik skorlarındaki değişim de incelenmek istenmiştir. 


\subsection{Araștırmanın Yöntemi}

Performans ve etkinlik değerlendirme yöntemleri genel olarak, parametrik ve parametrik olmayan yöntemler olarak ikiye ayrılmaktadır(Yücel 2017: 19-20). Parametrik olmayan yöntemler arasında en çok tercih edilen ise Veri Zarflama Analizi'dir (VZA) (İnan, 2000: 83). VZA çok sayıda girdi ve çok sayıda çıktının kullanılabildiği, parametrik olmayan doğrusal programlama özüne dayanan ayrıca herhangi bir fonksiyonel yapıya gerek duymayan ve etkinlik ölçümlerinde başarılı sonuçlar veren bir analiz türüdür (Cooper, Seiford ve Tone 2000: 2).

VZA'nın özündeki temel düşünce, kıyaslanabilir karar verme birimleri (KVB) içerisinde en iyi olanı belirleyecek ve etkin sınırı oluşturacak bir metodoloji sağlamaktır. Buna ek olarak, etkin sınırda olmayan birimlerin etkinlik düzeyini ölçmeye ve etkin olmayan birimlerin kıyaslanabileceği referans birimlerin belirlenmesine olanak sağlamaktadır (Cook ve Seiford 2009: 1-2). Etkin bulunmayan üretim birimleri için, bu etkinsiz durumun girdi kaynaklı mı yoksa çıktı kaynaklı mı olduğunu veya etkinsizliğin hangi girdi/hangi çıktıdan kaynaklandığını belirtmesi dolayısıyla sıkça kullanılan ve tercih edilen bir yöntem olmuştur. Yine etkin olmayan üretim birimleri, etkinliği sağlayabilmesi için ya da etkin olan üretim birimlerine benzeyebilmesi için tavsiyeler vermesi ve çözüm önermesi sebebiyle de kullanılmaktadır. VZA, etkin bulunmayan üretim birimlerinin, etkin olarak belirlenmiş üretim birimlerine oranla hangi girdi ya da çıktıyı azaltmalı/arttırmalı gibi öneriler sunmaktadır.

VZA yöntem itibariyle durum analizi yaptığından dolayı bütünüyle girdi ve çıktı eksenli bir mekanizması vardır. Bu nedenle girdi ya da çıtılların hatalı seçilmesi, muhtemel ölçüm yanlışları verimlilik skorlarının doğrudan yanlış ölçülmesine yol açacaktır. VZA'da, analize konu olacak karar verme birimleri sayısının belirlenmesi aşamasında da gerekli kıstaslar sağlanmalıdır. VZA, birden fazla sayıdaki girdi ve çıktı arasındaki ilişkileri gösteren ve diğer yöntemlere göre daha az varsayımla sonuca varabilen bir etkinlik analizi türüdür(Cooper, Seiford ve Zhu, 2004: 1-2) ve her bir gözlem için tek bir etkinlik değerinin bulunmasına olanak verir (Depren, 2008: 18). Yöntemin birden fazla sayıdaki girdi ve çıktı kullanılmasına olanak sağlaması, bu uygulamanın farklı alanlarda kullanılmasını sağlamıştır(Donthu ve Yoo 1998: 91).

VZA, etkin karar verme birimlerini belirlerken, etkin olmayan birimleri de saptamakta ve böylece etkinsizliği de ölçmektedir. Yöntem, etkin olmayan birimlerin, neden kaynaklı etkin olamadığını açık bir biçimde ortaya koymaktad ve kendilerine hangi etkin karar verme birimini referans alması gerektiğini, referans tayini yapmak yoluyla belirtmektedir (Charnes, Cooper ve Lewin, 1994: 25). VZA, ölçeğe göre sabit (Charnes-Cooper-Rhodes Modeli, CCR) ve ölçeğe göre değişken (BankerCharnes-Cooper Modeli, BCC) getiri altında etkinlik ölçümleri yapabilmektedir. Bu modeller kendi içlerindeki farklı teorik gelişimi ve uygulama yöntemleri çerçevesinde, girdi veya çıktı yönelimli olarak hesaplanmaktadır. 
CCR ve BCC modelleri "girdiye yönelik" ve "çıtıya yönelik" olmak üzere 2 farklı grupta ele alınmaktadır. Girdiye yönelik VZA modelleri belirli bir çıktı bileşiminin en etkin şekilde üretilebilmesi için en uygun girdi bileşiminin nasıl olması gerektiğini incelemektedir. Çıktıya yönelik VZA modelleri ise belirli bir girdi bileşimi kullanılarak en fazla ne kadar çıktı bileşiminin sağlanabileceğini araştırmaktadır (Altan, 2010: 190-191).

CCR model, ölçeğe göre sabit getiri varsayımını temel almaktadır(Ramanathan, 2003: 69). Bu varsayıma göre, girdide meydana gelen bir birimlik artış ya da azalış, çıktıda da bir birimlik artış ya da azalışa neden olmaktadır. $\mathrm{Bu}$ nedenle CCR model ölçeğe göre sabit getiri varsayımı ile tanımlanır(Forsund ve Sarafoglou 2002: 32).

Model, karar biriminin toplam etkinliğini, teknik etkinliğini ve ölçek etkinliğini tek bir değerde toplayıp toplam etkinliği hesaplamayı hedeflemektedir. CCR, toplam faktör verimliliğini temel aldığından, ağırlıklı toplam çıktıların ağılıklı toplam girdilere bölünmesi yoluyla etkinlik skorunu saptamaktadır (Charnes, Cooper ve Rhodes 1978: 430). Özetle, Veri Zarflama Analizinde temel etkinlik ölçütü, çıktıların ağırlıklı toplamlarının girdilerin ağırlıklı toplamlarına bölümüdür ve herhangi bir karar noktasının etkinlik skoru (j Karar noktası), (3.1) formülündeki gibi hesaplanabilir:

$$
\frac{u_{1} y_{1}+u_{2} y_{2}+\ldots+u_{n} y_{n}}{v_{1} x_{1}+v_{2} x_{2}+\ldots+v_{m} x_{m}}
$$

Denklem (3.1)'de j. karar noktası için $\mathrm{n}$ tane çıktı ve $\mathrm{m}$ tane girdi mevcuttur. Formülde, $u_{n} \mathrm{n}$ çıktının ağırlığını, $y_{n}$ çıktının miktarını, $v_{m}$ girdinin ağırlığını ve $x_{m}$ girdinin miktarını göstermektedir. Denklem (3.1)'den de anlaşıldığ üzere VZA kesirli bir programlama sürecini kapsamaktadır. Ancak kesirli programlamanın çözümü kolay olmamaktadır. Dolayısıyla, kesirli programlama seti, denklem (3.1)'in paydasının 1 olması gerekliliğine dayanarak doğrusal programlama setine çevrilebilir. Buna göre doğrusal programlama ile denklemi (3.2) ve (3.3.)'teki şekilde tanımlamak mümkündür.

$$
\begin{aligned}
& \text { Enbh }_{j}=\sum_{r=1}^{n} u_{r} y_{r} \\
& \sum_{i=1}^{m} v_{i} x_{i}=1 \\
& \sum_{r=1}^{n} u_{r} y_{r}-\sum_{i=1}^{m} v_{i} x_{i} \geq 0 \\
& u_{r}, v_{i} \geq 0 \\
& \mathrm{j}=0,1, \ldots . \mathrm{n} \\
& \mathrm{r}=1,2, \ldots . . \mathrm{s} \\
& \mathrm{i}=1,2, \ldots . . \mathrm{m} \\
& \mathrm{j}: \text { karar birimleri } \\
& \text { r:çıtılar }
\end{aligned}
$$


yrj:j. karar biriminin kullandığı $\mathrm{r}$ çıktısı miktarı

xij:j. karar biriminin kullandığı i girdisinin miktarı

Çıktı yönelimli CCR modelde doğrusal programlama setine ilişkin denklemler (3.4) ve (3.5)'deki gibidir:

$$
\begin{aligned}
& \operatorname{Enkg}_{j}=\sum_{i=1}^{m} v_{i} x_{i} \\
& \sum_{r=1}^{n} u_{r} y_{r}=1 \\
& -\sum_{r=1}^{n} u_{r} y_{r}+\sum_{i=1}^{m} v_{i} x_{i} \geq 0 \\
& u_{r}, v_{i} \geq 0
\end{aligned}
$$

CCR model hem girdi ya da çıktı odaklı kullanıldığında, karar verme birimlerinin etkinlik skorunun belirlenebilmesi için yukarıda bahsedilen model uygulanmalıdır. Modelin çözümüyle birlikte, karar verme birimlerinin etkinlik skorları ortaya çıkacaktır. Etkinlik skoru 0 ile 1 arasında bir değer ile ifade edilebilirken yüzdelik olarak da ifade edilebilir. Eğer bir karar verme biriminin etkinlik değeri 1 'den küçük ise bu, o karar verme biriminin etkin birimlere göre etkin olmadığı anlamına gelmektedir. Yani o birim göreli olarak etkin bulunmamış demektir. Etkinlik değeri 1'e eşit olan karar verme birimleri ise etkin birimler olarak kabul edilmektedir (Özbek 2007: 48-49).

$\mathrm{Bu}$ çalışmada, çıktı yönlü CCR model kullanılmaktadır. CCR model toplam etkinliği ölçmektedir. Çıktı yönlü modelin kullanılmasının nedeni, bir işletmede girdilerin azaltılmasından çok; çıktıların artırılmasının daha elverişli olmasıdır. Buna göre, aynı girdi bileşimi ile daha fazla çıktı elde edebilmenin mümkün olup olmadığı araştırılmaktadır. Ayrıca, kurulan VZA modeli, doğrusal programlama modülünün olduğu herhangi bir paket program ile çözülebilmektedir. Çalışma kapsamında, DEA Solver programı kullanılarak analiz yapılmıştır.

\subsubsection{Girdilerin Belirlenmesi}

Sigorta sektörü için temel girdiler emek (işgücü), sabit varlıklar(fiziksel sermaye) ve sermaye (finansal sermaye) dir(Cummins, Turchetti ve Weiss 1996:18). Bu temel girdiler sigorta sektörü için aynı zamanda üretim faktörleridir(Kılıçkaplan ve Baştürk 2004: 72). İlgili çalışmalara (Cummins ve Weiss (1993), Cummins ve Zi (1996), Barros, Barrossa ve Borges (2005), Kılıçkaplan ve Baştürk (2004), K1lıçkaplan ve Karpat (2004), Kayalı (2007), Özbek (2007), Kılınç (2009), Özcan (2011), Horasan (2013)) benzer şekilde; bu çalışma kapsamında da acente ayısı, sabit varlıklar, likit aktifler, özsermaye ve teknik karşı1ıklar girdi olarak alınmıştır.

Acente Sayısı: Sigorta şirketleri, ürettiği prim tutarını artırmak ve sigortalılara daha kolay ulaşabilmek için bazı kanallar ve aracılar kullanırlar. Bu dağıtım kanalları genel olarak acente ve 
brokerler olmaktadır (Özbek 2007: 85-86). Çalışma kapsamında, sigorta sektörü için temel girdilerden biri olan emek, acente sayısı ile ifade edilmektedir.

Sabit Varlıklar: Sabit varlıklar, literatürde yardımcı girdiler olarak da yer almaktadır (Cummins, Turchetti ve Weiss, 1996). Sabit varlıklar emek dışında kalan bütün fiziksel teçhizatları kapsamaktadır. Sigorta şirketlerinin faaliyetlerinde yararlandıkları her çeşit sabit varlığın etkin kullanılmasının şirket karlılığına faydası olmakta ve şirketlerin verimliliği konusunda etkili olmaktadır.

Likit Aktifler: Sigorta şirketleri için likit aktifler, meydana gelebilecek hasarları yüklenebilme kabiliyetini gösteren değerlerdir. Bir sigorta şirketi likidite yönünden yeterli ise hasarları ve şirket giderlerini karşılayabilecek güçtedir denebilir(Kahya 2001:162). Şirketlerin yaşayacağı likidite sorunları, sigortalılara olan yükümlülüklerin karşılanmamasına ve şirket giderlerinin ödenememesine sebep olmaktadır. Bu durumda şirketin etkinliği dolaylı olarak düşmektedir. Bunlardan dolayı likit aktifler sigorta şirketlerinin etkinliğinin ölçülmesinde bir girdi olarak alınmaktadır.

Özsermaye ve Teknik Karşılıklar: Sigorta şirketleri temel olarak iki güvenceyi üzerlerinde taşımaktadırlar. Bunlardan ilki mali yeterlilik diğeri hasarları karşılamada istekli ve hazırlıklı olma durumudur. Sigorta şirketlerinin mali yeterliliği özsermaye ve teknik karşılıkların düzeyine bağlı olarak değişmektedir. Özsermayenin, beklenmedik hasar ödemelerini karşılayabilmek için ve aynı zamanda yasal zorunluluk olarak güçlü olması gerekir. Özsermaye, sigortanın riski birleştirme ve üstlenme fonksiyonunu gerçekleştirebilmesi adına önemli bir girdidir (Turgutlu, Kök ve Kasman 2006).

\subsection{2. Çıktıların Belirlenmesi}

Literatürde sigorta şirketlerinin çıktılarının belirlenmesine dair birbirinden farklı yaklaşımlar mevcuttur. Gardner ve Grace (1993), prim üretimini çıktı olarak belirlemişlerdir. Ancak Yuengert (1993) çalışmasında primlerin sigortacılık hasılatını oluşturduğu dolayısıyla prim gelirlerinin girdi olması gerektiğini belirtmiştir. Çıktı olarak da prim üretimi yerine rezerv artış seviyelerinin kullanılmasını önermiştir. Ancak, Greene ve Segal (2004), rezervlerin çıktı olarak kullanılmasına olumlu bakmamışlardır. Bu konudaki görüşler genel olarak 3 başlık altında yoğunlaşmaktadır.

$\mathrm{Bu}$ yaklaşımlar; varlık (aktif) ya da aracılık yaklaşımı, kullanıcı maliyet yaklaşımı ve katma değer yaklaşımıdır (Cummins, Turchetti ve Weiss 1996: 16). Katma değer yaklaşımında, aktifte ya da pasifte yer alan herhangi bir kalemin çıktı olarak kullanılmasının ölçütü, o kalemin bir değer yaratması olarak belirlenmiştir. Bu yaklaşıma göre, aktif ya da pasifte yer alan kalemlerden herhangi biri eğer bir değer yaratıyorsa çıktı olarak kullanılabilir(Cummins, Turchetti ve Weiss 1996: 17), (Cummins, Tennyson ve Weiss, 1998: 325-357).

Sigorta şirketleri risk havuzlama ve risk taşıma, sigorta kayıpları ile ilişkili reel hizmetler ve finansal aracılık olarak özetlenen üç temel hizmeti sunarken katma değer yaratmaktadırlar. Çalışmada katma değer artışları çıktı olarak kabul edilmiştir. Buna göre, mali karlılık finansal aracılık hizmetlerinin yarattığı katma değerdir ve bu nedenle çalışmada çıktı olarak alınmıştır. Teknik karlılık ve alınan primler 
ise, risk havuzlama ve risk yüklenme hizmetlerinin yarattığı katma değer olarak bilinmektedir. Belirlenen çıktıların açıklaması şu şekilde olmaktadır:

Alınan Primler: Alınan primler sigorta şirketlerinin bir yıl içinde yaptıkları sigortacılık işlemleri neticesinde ürettikleri tüm primleri ifade etmektedir. Sigorta şirketlerinin aldığı primler, sektör için yatırım kaynağı görevindedir.

Teknik Kar: Finansal etkinliğin temel göstergesi karlılıktır. Sigorta şirketlerinde karlılıkları, teknik ve mali karlılık olarak iki kategoriden oluşmaktadır. Şirketlerin sigortacılık faaliyetleri neticesinde elde ettikleri tek kar olarak tanımlanmaktadır.

Mali Kar ${ }^{4}$ : Sigorta şirketleri ürettikleri primlerin belli bir kısmını yatırıma dönüştürmektedirler. Yaptıkları yatırımlar sayesinde şirket bünyesinde tahviller hisse senetleri, gayrimenkullerden meydana gelen bir portföy yaratılmaktadır. Şirketlerin bu tarz yatırımlardan elde ettikleri getiriler mali kar olarak ifade edilmektedir.

\subsection{Araştırmanın Kapsamı}

Çalışmada homojenliği sağlamak amacıyla, hayat dışı branşlarda faaliyet gösteren sigorta şirketlerinin etkinlik analizleri kendi içinde değerlendirilmiştir. Analizler en yakın tarihli yayınlanan 2018 verileri de dahil olmak üzere, 2013 ile 2018 yılları arasındaki zaman dilimini kapsamaktadır. Bazı girdi ve çıktı değişkenlerinin değeri "sıfır" olan, yıl içerisinde iflas eden ya da faaliyette bulunmayan KVB'ler (şirketler) analize dahil edilmemiştir.

Kullanılan veriler, T.C. Hazine ve Maliye Bakanlığı tarafından yayınlanan ve Sigortacılık ve Özel Emeklilik Raporlarında yer alan 2013- 2018 yılları arasındaki Sigortacıllk ve Bireysel Emeklilik Faaliyet Raporlarından derlenmiştir. Acente sayısı her sigorta şirketi için toplam acente sayısını belirtmektedir. Sabit varlıklar, Likit Aktifler, Özsermaye, Teknik Karşılıklar, Teknik Kar ve Mali Kar; yukarıda ifade edilen kaynaktaki sigorta şirketlerine ait bilanço ve gelir tablolarından derlenmiştir. Alınan Primler, yurtiçi ve yurt dışından direkt ve reasürans işlerinden alınan primlerden oluşmaktadır.

Analizde minimum KVB sayısı, girdi ve çıktı değişkenlerinin çarpımları kadar olmalıdır(Boussofiane, Dyson ve Thanassoulis, 1991). Çalışmada 4 girdi ve 3 çıktı değişkeni etkinlik belirleme sürecine dahil edildiği için KVB sayısı en az 12 olmalıdır. Buna göre, göre incelenen tüm dönemlerde yeterli sayıda KVB bulunmaktadır. Sirasiyla 2013-33, 2014-34, 2015-32, 2016-36, 2017 38 ve 2018-37 şirket analize dahil edilmiştir. Ayrıca VZA, KVB'lere ait girdi çıktı değişkenlerinden oluşan veri setlerinde negatif değer bulunması durumunda etkinlik analizini gerçekleştirememektedir. Bu durumda da, teknik olarak zarar eden sigorta şirketlerin çıktı değerleri negatif olacağından etkinlik analizi yapılamamaktadır. Ancak, konunun çözümü için literatürde veri seti içindeki en büyük negatif

\footnotetext{
${ }^{4}$ Çalışma kapsamında sigorta şirketlerinin bilançosunda yer alan yatırım gelirleri kalemi kullanılmıştır. Ancak literatürde yer alan çalışmalarda bu çıktı mali kar olarak tanımlanmıştır. Bu nedenle çalışmada da literatürle paralellik kurmak adına çıktı kaleminin adı mali kar olarak kullanılmıştır.
} 
değere sahip olan sayının mutlak değerinin 1 fazlası, veri setindeki tüm değerlere eklenmektedir. Böylece, veri setinde yer alan tüm negatif değerler sıfırlanmış olacak ve diğer veriler de pozitif hale getirilecektir(Thanassoulis, 2003: 112). Bu nedenle çalışmada teknik karı negatif değer olan sigorta şirketleri analiz dışında tutulmamış ve söz konusu yöntem uygulanarak veri seti negatif değerlerden arındırılmıştır. Analizde kullanılan girdi ve çıktı değişkenleri Tablo 1'de özetlenmiştir.

Tablo 1: Analizde Kullanılan Girdi ve Çıktı Değişkenleri

\begin{tabular}{|c|c|c|c|}
\hline \multicolumn{2}{|r|}{ GİRDí } & \multicolumn{2}{|c|}{ ÇIKTI } \\
\hline (G1) & Acente Say1s1 & (Ç1) & Alınan Primler \\
\hline (G2) & Sabit Varl1klar & (Ç2) & Teknik Kar \\
\hline (G3) & Likit Aktifler & (Ç3) & Mali Kar \\
\hline (G4) & Özsermaye ve Teknik Karsslliklar & & \\
\hline
\end{tabular}

\section{Bulgular}

\subsection{Türk Sigorta Sektörü Kapsamında 2002 ve 2018 Yıllları}

Türk Sigorta Sektörü’ne ait bazı göstergelerin 2002 ile 2018 yıllarındaki genel görünümü incelendiğinde (Tablo:2); hayat dışı şirket sayısı 30 dan 38'e yükselmiş, hayat dışı branşların sektör içinde payı \%82-\%83 aralığında kalmıştır. Primlerin nominal artış oranında azalmalar yaşanırken, reel artış oranlarında negatif değerler görülmüştür. 2002 yılında dağıtım kanalları içinde acentelerin payı $\% 64$ iken, 2018'de \%58 olarak gerçekleşmiş, merkezin payı ise \%20'lerden \%4'e düşerek büyük oranda azalmıştır. Sigorta işlemi yapan bankaların payı ise \%9'dan \%24'e yükselmiş ve sigorta sektöründe bankaların payı artış göstermiştir.

Tablo: 2 Türk Sigorta Sektörüne Ait Göstergelerin 2002 ve 2018 Yılı Değerleri

\begin{tabular}{lrrrr}
\hline & 2001 & 2002 & 2017 & 2018 \\
\hline Hayat-dış1 şirket sayısı & 30 & 30 & 38 & 38 \\
Hayat şirket sayısı & 29 & 29 & 22 & 22 \\
Reasürans şirketi sayısı & 3 & 3 & 2 & 2 \\
Hayat-dışı sektörel payı & 0,82 & 0,82 & 0,82 & 0,83 \\
& & & & 14, \\
Primlerin nominal artış oranı & 41,06 & 45,03 & 11,48 & 64 \\
Primlerin reel artış oranı & $-25,19$ & 10,75 & 3,43 & $-1,46$ \\
Merkezin pay1 & 0,21 & 0,20 & 0,05 & 0,04 \\
Acente pay1 & 0,65 & 0,64 & 0,52 & 0,58 \\
Banka acentelerinin payı & 0,09 & 0,09 & 0,31 & 0,24 \\
Broker kuruluşlarının pay1 & 0,05 & 0,07 & 0,11 & 0,12 \\
Teknik Kar/Prim oranı & 9,70 & 9,30 & 5,83 & 7,60 \\
Bilanço Karı/Aktif Toplamı & 7,20 & 5,27 & 4,14 & 5,01 \\
Özsermaye Karlılığ1 & 40,90 & 24,46 & 21,24 & 29,23 \\
Genel Giderler/Prim oranı & 18,87 & 15,48 & 12,66 & 9,85 \\
\hline
\end{tabular}


Kaynak: Hazine ve Maliye Bakanlı̆̆l, Sigortacılık ve Bireysel Emeklilik Sistemi Hakkında Faaliyet Raporları dikkate alınarak araştırmacılar tarafindan hazırlanmıştır.

Sigorta şirketlerinin rekabet ettiği bir alanda temel hizmet alanı sigortacılık olmayan bankaların payının artması, sigorta sektörü ve acenteler için ciddi uyarılar taşımaktadır. Teknik kar /prim oranı 2002 yılında \%9,70 iken, 2018 yılında \%7,60 seviyesindedir. Özsermaye karlılığ \%40'dan, \%29'lara düşmüştür.

\subsection{Yılında Analizde Yer Alan Sigorta Şirketlerinin 2018 Yılındaki Durumu}

Yaklaşı 16 yıl arayla yapılan analiz sonuçlarında; 2002 yılında 30 şirket ele alınırken 2018 yılında değişikliklerle birlikte 37 şirket kapsama alınmıştır (Tablo:3).

Tablo: 32002 Yllında Analizde Yer Alan Sigorta Şirketlerinin 2018 Yllındaki Durumu

\begin{tabular}{|c|c|c|c|}
\hline 2002 & 2018 & 2002 & 2018 \\
\hline AKDENİZ & İflas & HÜR & $\begin{array}{l}\text { İflas } \\
\end{array}$ \\
\hline AKSİGORTA & AKSİGORTA & IŞIK & BEREKET \\
\hline ANADOLU ANONIM TÜRK & ANADOLU & İHLAS & HDI (satın alındı) \\
\hline ANKARA ANONIM TÜRK & ANKARA & İSVIÇRE & ERGO \\
\hline AXA OYAK & AXA & RAY & RAY \\
\hline BAŞAK & GROUPAMA & RUMELİ & TMSF'ye devredildi \\
\hline BATI & Güvence Hesabına Devredildi & SANKO & İflas \\
\hline BİRLİK & HALK & ŞEKER & $\mathrm{SBN}=$ ŞEKER \\
\hline COMMERCIAL UNION & UNICO (AVIVA) & TEB & ZURICH \\
\hline EGE & İflas & TİCARET & SBN \\
\hline FINANS & SOMPO JAPAN & T.GENEL & MAPFRE \\
\hline GARANTİ & EUREKO & T.NIPPON & TURKNIPPON \\
\hline GENERALİ & GENERALİ & TOPRAK & $\begin{array}{l}\text { Ege Sigorta ald, Ege Sigorta iflas } \\
\text { etti }\end{array}$ \\
\hline GÜNEŞ & GÜNEŞ & $\begin{array}{l}\text { YAPI } \\
\text { KREDİ }\end{array}$ & ALLİANZ \\
\hline GÜVEN & GROUPAMA & & \\
\hline KOÇ ALLIANZ & ALLİANZ & & \\
\hline
\end{tabular}

2002 yılında hayat dışı alanda faaliyet gösteren şirketlerinin 2018 y1lındaki durumları incelendiğinde; sadece 7'sinde herhangi bir değişiklik olmazken, diğerlerinde ise, isim veya ortak değişikliği, iflas ve TMSF'ye devirler söz konusu olmuştur. Sigortalı olan bir kişinin 16 yıl boyunca poliçeleri aynı şirketle yaptırabilme olasılığının oldukça düşük olduğu söylenebilir. 


\subsection{Hayat dışı Sigorta Şirketleri için 20013- 2018 Yılları Etkinlik Skorları}

2013 ve 2018 yılları arasındaki dönemde sürekli olarak faaliyet gösteren sigorta şirketlerinin, çıktı yönelimli CCR modeldeki etkinlik skorları Tablo 4'te yer almaktadır. Buna göre 22 sigorta şirketi 2013 ve 2018 y1lları arasında faaliyetlerine kesintisiz şekilde devam etmişlerdir. 22 sigorta şirketinin etkinlik değerlerinin en yüksek olarak gözlendiği yıllar 2014 ve 2015 yılları olmuştur. Bu yıllarda 22 sigorta şirketinin 11 tanesi görece etkin olarak gözlenmiştir. 2013 ve 2016 yıllarında ise, 22 sigorta şirketinden 3'ü görece etkin bulunmuştur. 2017 ve 2018 y1llarında etkin olarak gözlenen sigorta şirketi sayısı 4'te kalmıştır. Bu durum Tablo 4'te ifade edilmektedir.

Tablo:4 Çıktı Yönelimli CCR Model Etkinlik Skorları (2013 ve 2018 Yılları Arasında Kesintisiz Faal Olan Şirketler)

\begin{tabular}{|c|c|c|c|c|c|c|c|}
\hline \multicolumn{2}{|c|}{ Sirketler } & 2013 & 2014 & 2015 & 2016 & 2017 & 2018 \\
\hline 1 & AKSİGORTA & 0,8519 & 1 & 1 & 0,6404 & 0,7273 & 0,7506 \\
\hline 2 & ALLIANZ & 1 & 1 & 1 & 0,572 & 0,7222 & 0,4474 \\
\hline 3 & ANADOLU & 0,8635 & 0,8033 & 0,8792 & 0,4958 & 0,581 & 0,5238 \\
\hline 4 & ANKARA & 0,6267 & 1 & 0,5886 & 0,3703 & 0,7019 & 0,5311 \\
\hline 6 & AXA & 0,9403 & 1 & 1 & 0,7523 & 0,7326 & 0,3467 \\
\hline 7 & BEREKET & 0,5464 & 0,6122 & 0,6485 & 0,4919 & 0,5584 & 0,5699 \\
\hline 8 & $\begin{array}{ll}\text { BNP } & \text { PARIBAS } \\
\text { CARDIF } & \end{array}$ & 0,7308 & 1 & 1 & 1 & 1 & 1 \\
\hline 9 & COFACE & 0,7308 & 1 & 1 & 1 & 1 & 1 \\
\hline 10 & DUBAI STARR & 0,67 & 1 & 0,9359 & 0,5903 & 0,7402 & 1 \\
\hline 11 & ERGO & 1 & 1 & 1 & 0,8902 & 0,8724 & 0,4293 \\
\hline 12 & EULER HERMES & 1 & 1 & 1 & 0,7742 & 1 & 1 \\
\hline 13 & EUREKO & 0,724 & 0,892 & 1 & 0,5801 & 0,7277 & 0,6187 \\
\hline 14 & GROUPAMA & 0,6017 & 0,6618 & 0,6037 & 0,2696 & 0,459 & 0,4766 \\
\hline 15 & GUNES & 0,7528 & 0,8411 & 0,7511 & 0,2562 & 0,4962 & 0,599 \\
\hline 16 & HALK & 0,7237 & 0,8592 & 1 & 1 & 1 & 0,9298 \\
\hline 17 & HDI & 0,5653 & 0,678 & 0,6711 & 0,3451 & 0,5437 & 0,5537 \\
\hline 18 & MAPFRE & 0,9394 & 1 & 1 & 0,3533 & 0,6933 & 0,5611 \\
\hline 19 & NEOVA & 0,9711 & 1 & 1 & 0,8049 & 0,8222 & 0,4617 \\
\hline 20 & RAY & 0,6506 & 0,6688 & 0,7317 & 0,3039 & 0,5198 & 0,8109 \\
\hline 21 & SBN & 0,8662 & 0,9122 & 0,9748 & 0,421 & 0,4576 & 0,4979 \\
\hline 22 & SOMPO JAPAN & 0,6357 & 0,7259 & 0,8396 & 0,3966 & 0,4875 & 0,4584 \\
\hline
\end{tabular}

Tablo 4'e göre, BNP ve Coface Sigorta 2014 ve 2018 yılları arasında yer alan her dönemde görece etkin olarak gözlenmiştir. Allianz ve Aksigorta şirketleri, 2014 ve 2015 y1llarında görece etkinken; 2016 yılından itibaren etkinlik skorları 1'in altında kalmıştır. Allianz Sigorta Aksigortadan farklı olarak, 2018 yılında daha belirgin bir etkinlik düşüşü yaşayarak, incelenen dönemler içindeki en düşük seviyesine gerilemiştir. Bunun yanısıra, Anadolu, Bereket, Groupama, Güneş, HDI, Ray, SBN ve Sompo Sigorta incelenen dönemlerin tümünde etkin olarak gözlenemeyen sigorta şirketleri olmuşlardır. 


\subsection{Hayat dışı Sigorta Şirketleri için 2002 ve 2018 Yılları Etkinlik Skorlarının}

\section{Karşılaştırılması}

2018 yılında hayat dışı branşlarda faaliyet gösteren ve analize dahil edilen sigorta şirketi sayısı 37'dir. 2018 y1lı için etkin bulunan sigorta şirketi sayısı CCR modelde 7, BCC modelde ise 15'tir. Söz konusu 37 şirkete ait CCR etkinlik skorları 3 çıktı ve herbir çıktı için hesaplanmış ve Tablo:5'de özetlenmiştir.

Tablo: 52018 Yılında Faaliyette Bulunan Hayat-Dışı Sigorta Şirketlerine Ait Etkinlik Değerleri

\begin{tabular}{|c|c|c|c|c|}
\hline \multicolumn{2}{|c|}{ Etkinlik Değeri (3 Çıktı Iç̧in) } & \multicolumn{3}{|c|}{ Etkinlik Değeri (1 Çıktı İçin) } \\
\hline Sigorta Şirketleri & Etkinlik Değeri & $\begin{array}{l}\text { Alınan Primler } \\
\text { Etkinlik Dĕ̌eri }\end{array}$ & $\begin{array}{l}\text { Teknik Kar } \\
\text { Etkinlik Değeri }\end{array}$ & $\begin{array}{l}\text { Mali Kar } \\
\text { Etkinlik Değeri }\end{array}$ \\
\hline AKSIGORTA & 0,7506 & 0,7506 & 0,0798 & 0,2612 \\
\hline ALLIANZ & 0,4474 & 0,4466 & 0,0258 & 0,1777 \\
\hline ANADOLU & 0,5238 & 0,5165 & 0,0313 & 0,244 \\
\hline ANKARA & 0,5311 & 0,5311 & 0,1341 & 0,2405 \\
\hline ATRADIUS & 0,8442 & 0,6364 & 0,8442 & 0,1611 \\
\hline AXA & 0,3467 & 0,327 & 0,0369 & 0,2273 \\
\hline BEREKET & 0,5699 & 0,5699 & 0,0552 & 0,1168 \\
\hline BNP PARIBAS CARDIF & 1 & 0,4144 & 1 & 0,3809 \\
\hline CHUBB & 1 & 1 & 1 & 0,1744 \\
\hline COFACE & 1 & 1 & 1 & 1 \\
\hline CORPUS & 0,6134 & 0,6072 & 0,3881 & 0,142 \\
\hline DOGA & 0,8977 & 0,8977 & 0,038 & 0,2128 \\
\hline DUBAI STARR & 1 & 1 & 0,8971 & 1 \\
\hline ERGO & 0,4293 & 0,4167 & 0,0728 & 0,2703 \\
\hline ETHICA & 0,9211 & 0,9211 & 0,1479 & 0,2883 \\
\hline EULER HERMES & 1 & 0,8277 & 1 & 1 \\
\hline EUREKO & 0,6187 & 0,6166 & 0,0428 & 0,2306 \\
\hline GENERALI & 0,4709 & 0,4709 & 0,1203 & 0,1547 \\
\hline GROUPAMA & 0,4766 & 0,4766 & 0,0336 & 0,1417 \\
\hline GULF & 0,6256 & 0,6066 & 0,1319 & 0,4165 \\
\hline GUNES & 0,599 & 0,599 & 0,0208 & 0,2593 \\
\hline HALK & 0,9298 & 0,8297 & 0,0785 & 0,6498 \\
\hline HDI & 0,5537 & 0,5537 & 0,0315 & 0,1419 \\
\hline KORU & 0,7339 & 0,7339 & 0,2589 & 0,1516 \\
\hline MAGDEBURGER & 0,5679 & 0,3107 & 0,5679 & 0,1128 \\
\hline MAPFRE & 0,5611 & 0,5611 & 0,0063 & 0,1698 \\
\hline NEOVA & 0,4617 & 0,4617 & 0,085 & 0,1203 \\
\hline ORIENT & 0,828 & 0,6728 & 0,6649 & 0,828 \\
\hline QUICK & 0,7351 & 0,7351 & 0,0688 & 0,0973 \\
\hline RAY & 0,8109 & 0,8109 & 0,0618 & 0,2307 \\
\hline SBN & 0,4979 & 0,4962 & 0,1219 & 0,1666 \\
\hline SOMPO JAPAN & 0,4584 & 0,4292 & 0,0511 & 0,3426 \\
\hline TURK NIPPON & 0,6604 & 0,6604 & 0,1056 & 0,1066 \\
\hline TURK P\&I & 1 & 1 & 1 & 0,7233 \\
\hline
\end{tabular}




\begin{tabular}{lcccc} 
UNICO & 0,7477 & 0,7477 & 0 & 0,2258 \\
ZIRAAT & 1 & 1 & 1 & 1 \\
ZURICH & 0,4768 & 0,4533 & 0,1374 & 0,2566 \\
\hline
\end{tabular}

Herbir çıktı için analiz yapıldığında, etkin şirket sayısında azalmalar olduğu görülmektedir. Aksigorta, Allianz, Anadolu, Axa, Halk, Güneş, Gulf, Sompo Japan ve Zurich Sigorta ölçek etkinliğinden arındırılmış olarak incelendiğinde, teknik etkinliği sağlamışlardır. Ancak bu şirketlerin toplam etkinlik skorları 1'in altında kalmıştır.

2002 yılında yapılan VZA sonuçlarında; alınan primler çıktısına göre sadece 2 şirket etkin iken, mali karda 9 şirket etkin olarak bulunmuştur. Mali kar çıktısına göre etkin olan şirketlerin aracılık fonksiyonuna daha çok ağırlık verdiği söylenebilir. Tüm girdiler açısından incelendiğinde; en çok iyileştirme yapılması gereken girdi sabit varlıklar olurken buna karşın en az iyileştirme gerektiren girdi ise likit aktiflerdir. Çıktılar açısından potansiyel iyileştirme oranları incelendiğinde ise; çok daha yüksek oranlarda artış olması gerektiği sonucuna ulaşılmıştır. (K1lıçkaplan ve Baştürk 2004: 64)

2018 yılında sigorta şirketlerinin teknik kar çıktısında büyük oranlarda iyileştirmeler yapmaları tavsiye edilmiştir. Hayat dışı branşta faaliyette bulunan sigorta şirketlerinin etkinlik düşüşleri yaşamalarının en önemli nedeni teknik kar çıktısında etkinliği istenilen düzeyde tutamamış olmalarıdır. Bu çıktıda yaşanan etkinsizlikler mali kar çıktısında da etkinsizliğe neden olmaktadır. Etkinsiz bulunan sigorta şirketlerine ait iyileştirmeler Tablo 6'da verilmiştir.

Tablo: 62018 Yllına Ait İyileştirme Tablosu

\begin{tabular}{|r|l|r|r|r|}
\hline \multirow{2}{*}{\multicolumn{2}{|c|}{ Şirketler }} & \multicolumn{2}{c|}{ CCR MODEL \% ARTIŞLAR ÇIKTILAR } \\
\cline { 2 - 5 } & $\begin{array}{c}\text { Alınan Primler } \\
\text { (Çıktı 1) }\end{array}$ & $\begin{array}{c}\text { Teknik Kar } \\
\text { (Çıtı 2) }\end{array}$ & $\begin{array}{c}\text { Mali Kar } \\
\text { (Çıktı 3) }\end{array}$ \\
\hline $\mathbf{1}$ & AKSİGORTA & 33 & 209 & 44 \\
\hline $\mathbf{2}$ & ALLIANZ & 123 & 1696 & 123 \\
\hline $\mathbf{3}$ & ANADOLU & 91 & 1389 & 134 \\
\hline $\mathbf{4}$ & ANKARA & 88 & 386 & 307 \\
\hline $\mathbf{5}$ & ATRADIUS & 32 & 18 & 188 \\
\hline $\mathbf{6}$ & AXA & 188 & 796 & 274 \\
\hline $\mathbf{7}$ & BEREKET & 75 & 349 & 0 \\
\hline $\mathbf{8}$ & BNP PARIBAS CARDIF & 0 & 0 & 0 \\
\hline $\mathbf{9}$ & CHUBB & 0 & 0 & 0 \\
\hline $\mathbf{1 0}$ & COFACE & 0 & 0 & 294 \\
\hline $\mathbf{1 1}$ & CORPUS & 63 & 63 & 113 \\
\hline $\mathbf{1 2}$ & DOĞA & 11 & 674 & 0 \\
\hline $\mathbf{1 3}$ & DUBAI STARR & 0 & 0 & 132 \\
\hline $\mathbf{1 4}$ & ERGO & 133 & 489 & 16 \\
\hline $\mathbf{1 5}$ & ETHICA & 8 & 93 & 0 \\
\hline $\mathbf{1 6}$ & EULER HERMES & 0 & 0 & 62 \\
\hline $\mathbf{1 7}$ & EUREKO & 62 & 1068 & 180 \\
\hline $\mathbf{1 8}$ & GENERALI & 112 & 116 & 229 \\
\hline $\mathbf{1 9}$ & GROUPAMA & 110 & 1398 & 60 \\
\hline $\mathbf{2 0}$ & GULF & 60 & 293 & \\
\hline
\end{tabular}




\begin{tabular}{|c|c|c|c|c|}
\hline 21 & GUNES & 67 & 4718 & 179 \\
\hline 22 & HALK & 7 & 618 & 7 \\
\hline 23 & HDI & 81 & 840 & 208 \\
\hline 24 & KORU & 36 & 66 & 228 \\
\hline 25 & MAGDEBURGER & 189 & 76 & 650 \\
\hline 26 & MAPFRE & 78 & 9001 & 179 \\
\hline 27 & NEOVA & 117 & 332 & 325 \\
\hline 28 & ORIENT & 43 & 39 & 21 \\
\hline 29 & QUICK & 36 & 487 & 372 \\
\hline 30 & RAY & 23 & 540 & 99 \\
\hline 31 & SBN & 101 & 101 & 163 \\
\hline 32 & SOMPO JAPAN & 118 & 841 & 118 \\
\hline 33 & TURK NIPPON & 51 & 323 & 325 \\
\hline 34 & TURK P\&I & 0 & 0 & 0 \\
\hline 35 & UNICO & 34 & 56799513 & 149 \\
\hline 36 & ZiRAAT & 0 & 0 & 0 \\
\hline 37 & ZURICH & 110 & 194 & 110 \\
\hline
\end{tabular}

Tablo 6'ya göre; BNP, Chubb, Coface, Dubai, Euler Helmes, Turk P\&I ve Ziraat Sigorta şirketleri 2018 yılında toplam etkinliği sağlamışlardır. Bu şirketlerin dışındaki diğer sigorta şirketleri görece etkinsiz bulunmuşlardır. Etkinsiz bulunan şirketlerin özellikle teknik kar çıtısında büyük oranlarda iyileştirmeler yapmaları önerilebilir. Örneğin; Allianz, Anadolu, Ankara, Axa, Bereket, Doğa, Ergo, Eureko, Groupama, Güneş, Halk, HDI, Mapfre, Neova, Quick, Ray, Sompo, Turk Nippon ve Unico Sigorta şirketlerinin teknik kar çıtılarındaki bozulmalar, sayılan bu şirketlerin etkinsiz olarak gözlenmesinin en güçlü nedenlerinden biridir.

Etkinsiz olarak gözlenen sigorta şirketlerinin, sahip oldukları girdi bileşimleri ile daha fazla üretim yapabilmeleri mümkündür. Analiz sonucuna göre, genel olarak sigorta sektörünün gerçekleştirilen prim üretiminde görece küçük oranlı iyileştirmeler yapmaları gerekli görülmüştür. Ancak gerçekleşen üretimin karlılığa katkı sunması noktasında sorunlar olduğu anlaşılmaktadır. Yani üretimin olması gerekenden daha düşük kalmasından ziyade, gerçekleşen üretimin çoğu zaman karlılığa yansıyamaması söz konusudur. Bu noktada, sigorta şirketlerinin hasar-prim oranının düşük seyrettiği sigorta branşlarına yönelmesi şirket karlılığına katkı sunabilecektir.

\subsection{Sektör Etkinlik Ortalamaları}

Şirket bazında etkinlik skorlarının değerlendirilmesine bağlı olarak sektör etkinlik ortalamalarının incelenmesi ele alınmıştır (Grafik: 1). Bu kapsamda, 2013 yılında hayat dışı branşta faaliyet gösteren sigorta şirketlerinin etkinlik ortalaması CCR modelde 0,82 olmaktadır. Girdi yönelimli BCC modelde sektör ortalama etkinlik değeri 0,92 iken; çıktı yönelimli BCC modelde sektör ortalama etkinlik değeri 0,94 olarak gözlenmektedir. Şirketlerin teknik etkinlik skoru yani BCC model etkinlik skoru oldukça yüksek bir ortalamaya sahiptir. Buna göre, şirketlerin büyük çoğunluğu teknik yönden etkindir. Ancak ölçek etkinliğini de içinde barındıran toplam etkinlik yani CCR model etkinlik, BCC 
model etkinliğe göre daha düşük kalmaktadır. Yani sigorta şirketlerinin bir kısmı teknik etkin olsalar bile ölçek etkinliğine sahip değillerdir. Dolayısıyla toplam etkinlik değerleri 1'in altındadır.

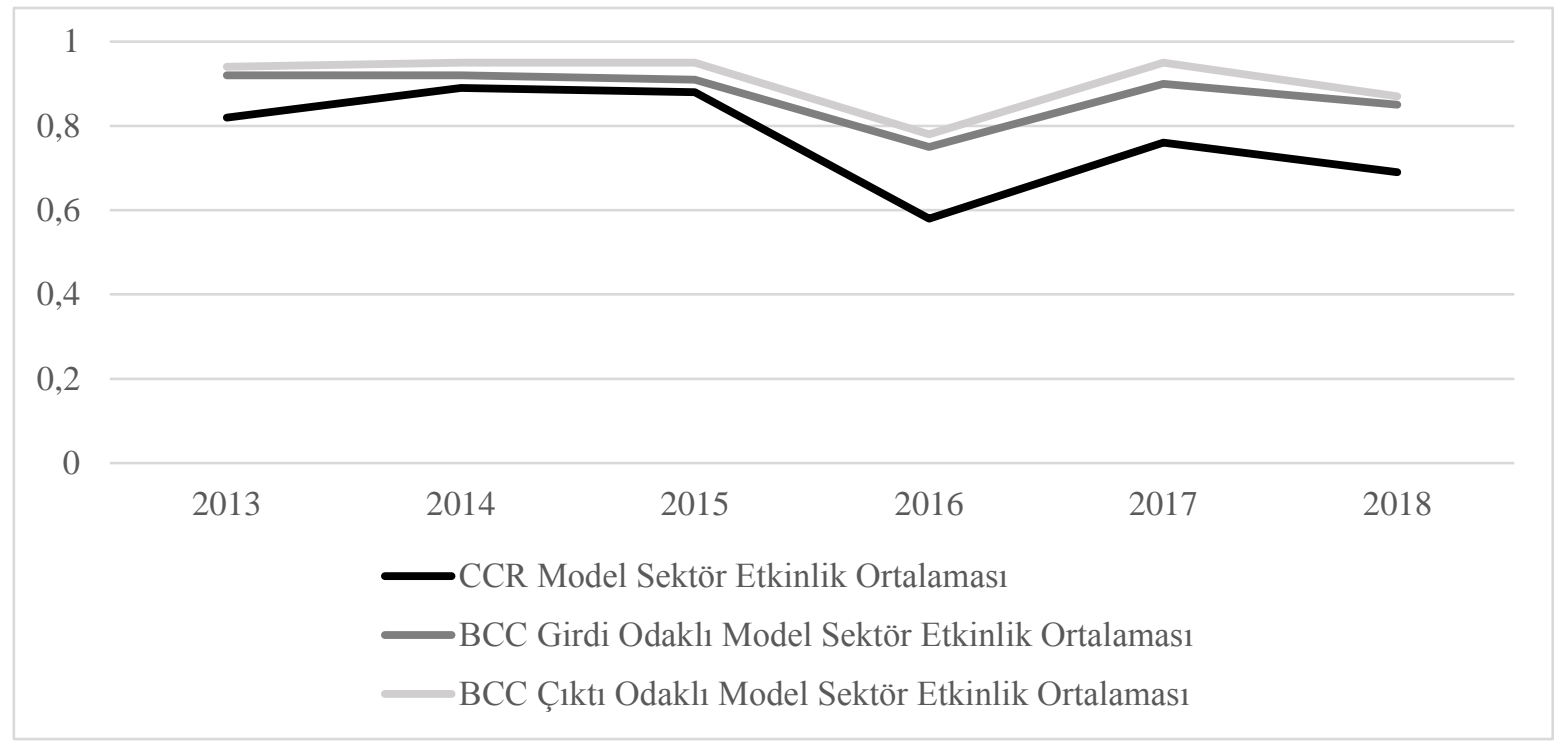

Grafik 1. Hayat Dışı Branş Ortalama Etkinlik Skorları

2014 yılında, BCC özellikle çıktı yönelimli modelde sektör ortalama etkinlik skorları oldukça yüksek seyretmektedir. Ancak toplam etkinlik skorları teknik etkinlik skorlarından yaklaşık 1 puan daha aşağıda yer almaktadır. $\mathrm{Bu}$ durumda bazı şirketlerin ölçek etkinliğini sağlayamadığından bahsedilebilmektedir.

2015 yılında çıktı yönelimli BCC modeldeki sektör ortalama etkinlik skoru 2014 y1lıyla aynı değeri vermektedir. Bir önceki yıla göre toplam etkinliği sağlayan sigorta şirketlerin sayısında artış olduğu görülmüştür. Teknik etkinliklerin ortalama sonuçlarında girdi yönelimli olarak çok az miktarda bir değişim söz konusudur.

Grafik 1'e göre, 2016 yılında CCR modelde etkinlik skoru ortalaması 0,58 olarak bulunmuştur. Girdi yönelimli BCC modelde etkinlik skoru ortalaması 0,75; çıktı yönelimli BCC modelde etkinlik skoru ortalaması 0,78'dir. 2016 y1lında sigorta şirketlerinin etkinliği her iki modelde de düşmüştür. 2016 yılında sigorta şirketlerinin büyük çoğunluğu hem teknik hem de ölçek etkinliğinde bir önceki yıla oranla etkinsizdirler. Özellikle CCR modelde etkinlik skorları sert bir düşüş yaşamıştır. Bir önceki yılda toplam etkinliği sağlayan sigorta şirketlerinin 2016 yılında etkinlik skorları büyük oranda düşmüştür. 2017 yılında ise, etkinlik skorlarında çok yüksek olmasa da bir önceki yıla oranla bir toparlanma olduğu gözlenmektedir. 2018 yılında da sigorta sektörünün hayat dışı branşında etkinlik düşüşü olduğu Grafik 1 'den anlaşılmaktadır. Hem CCR modelde hem de BCC modelde bir önceki yıla oranla sektör etkinlik ortalamaları daha düşük olarak gözlenmiştir. 


\section{Sonuç ve Genel Değerlendirme}

Sigortacılık sektörünün istikrarlı büyüme göstermesi ve finansal piyasalardaki işlevinin artıp kalıcılaşması için sigorta şirketleri teknik karlılıklarını artırmalıdırlar. Hayat dışı branşlarda 2013 ve 2018 yılları arasındaki döneme ait olarak yapılan etkinlik analizleri sonuçlarına göre, sektörün etkinliği 2016 yılında büyük oranda düşmüştür. Toplam etkinliği sağlayabilen sigorta şirketi sayısının 6'da kalması ve diğer 30 şirketin görece etkinsiz olarak gözlenmesi, sektörün geneli için oldukça olumsuz bir sonuç olarak değerlendirilebilir. Yine söz konusu sigorta şirketlerinin özellikle çıtı bileşimlerinde büyük oranda iyileştirmeler yapması gerektiği gözlenmiştir.

2017 y1lında 25 sigorta şirketinin teknik etkin olduğu ancak bunların 14'ünün ölçek etkinliğini sağlayamadıkları ve dolayısıyla toplam etkin olamadığı gözlenmiştir. Toplam etkinliği sağlayabilen sigorta şirketi sayısı 11'de kalmıştır. 2016 y1lına göre 2017 y1lı daha olumlu bir y1l olmuş ve ilgili şirketlerin etkinlik ortalaması da CCR modelde 0,58 'den 0,76 'ya, BCC modelde 0,70 'lerden 0,90 'lara yükselmiştir.

İncelenen dönemler içinde; 2016 yılında olduğu kadar düşük etkinlik skorları tekrarlanmasa da, 2018 y1lında da hayat dış1 branşlarda etkinlik düşüşü olduğu görülmüştür. 2018 y1lında sigorta şirketlerinin teknik kar çıktısında büyük oranlarda iyileştirmeler yapmaları tavsiye edilmiştir. Söz konusu sigorta şirketlerinin etkinlik düşüşleri yaşamalarının en önemli nedeni teknik kar çıktısında etkinliği istenilen düzeyde tutamamış olmalarıdır. Bu çıktıda yaşanan etkinsizlikler yatırım gelirleri çıktısında da etkinsizliğe neden olmaktadır.

Ekonomide beklenmedik olumsuzlukların yaşanmasına hazırlıklı olmak ve bu olumsuzluklardan en az seviyede etkilenmek için teknik karlılık seviyesi ve özsermaye yapısının güçlülüğü sigorta şirketleri için hayati önemdedir. Sigorta sektörü ve özellikle hayat dış1 branşı genel ekonomik göstergelerden oldukça etkilenmektedir. Bu kapsamda 2018 y1lında yaşanan kur dalgalanmalarının, talepte yaşanan azalışların ve ekonomik durgunluğun sigorta şirketlerini de etkilediği ve etkinlik skorlarının bir önceki yıla oranla aşağı yönlü seyir izlemesinin nedenlerinden biri olduğu gözlenmiştir.

Çalışma kapsamında sektör pazar payının büyük çoğunluğunu elinde bulunduran görece daha büyük ölçeğe sahip olan sigorta şirketleri, kendinden daha küçük ölçekte hizmet sunan sigorta şirketlerine göre etkinsiz olarak gözlenmiştir. Sigorta şirketlerinin ölçek büyüklüğü ile etkinlikleri arasında ilişki olduğu, Cummins ve Weiss (1993), Rai, (1996) çalışmalarında da ifade edilmiş ve büyük şirketlerinin etkinlik skorları konusunda farklı bulgular gözlemlenmiştir. Ülke bazında sektörün yapısından kaynaklanan farklılıkların bunun nedenleriden biri olduğu söylenebilir.

2002 yılında faaliyette bulunan hayat dışı şirketler için, en çok iyileştirme yapılması gereken girdi sabit varlıklar iken likit varlıklar yeterli bulunmuştur. 2018 yılında da yukarıda ifade edildiği gibi, görece büyük şirketlerin etkinsiz olarak görülmesi benzer şekilde etkin kullanılamayan sabit 
varlıklardan kaynaklanabilir. Özellikle dağıtım kanalları içinde acentelerin payının azalırken bankaların payının artması da sektör ve acenteler için ciddi bir uyarı niteliğindedir.

İncelenen dönem içinde; farklı yıllarda sektör genelinde etkinlik düşüşleri sonucuna ulaşan çalışmalara (K1lıçkaplan ve Karpat, 2004, Altan 2010, Horasan, 2013, Özcan, 2011), benzer şekilde 2018 yılı da etkinlik düşüşünün yaşandığı bir yıl olmuştur. Sektör genelinde etkinlik düşüşleri nedenleri olarak sektörün veya branşların prim üretimindeki yetersizliği (Kayalı, 2007), şirketlerin bozulan sermaye yapısı (Kılıçkaplan ve Karpat, 2004) veya yönetsel kararlardaki yetersizlikler (Horasan, 2013, Altan, 2010) olarak ifade edilmiştir. Bu çalışma kapsamında da 2002 yılında hayat dışı branşlarda faaliyette bulunan 30 sigorta şirketinden sadece 7'sinde bir değişiklik olmadığı, diğerlerinde ise yönetimlerinde, kurumsal yapılarında ciddi değişimler yaşandığı görülmüştür. 16 yıl gibi kısa bir zaman diliminde sigorta şirketlerinin kurumsal yapılarında ciddi değişiklikler yaşanması ve iflas veya fona devredilme sonucu sektörün uzun vadeli planlama yapmasında ve uygulamasında ciddi olumsuzluklar yaratabilecektir. Özellikle poliçe sahiplerinin veya potansiyel sigortalıların sektöre duyacakları güven duygusu bu değişimlerden negatif etkilenebilecektir.

Araştırma kapsamında elde edilen bulgulara bağlı olarak; 2018 yılında yaşanan etkinlik skorlarındaki düşüşlere dikkat çekilmek istenmiş ve 2019 yılı ve sonrası için, ilgili skorların yükseleceği ya da düşüş eğiliminin devam edip etmeyeceği konusunda soru işaretleri oluşmuştur. Düşüşün devam etmesi durumunda sektörü 2016 yılından daha düşük etkinlik skorları beklemektedir. Bu da yeterli prim seviyesine ulaşılamaması, karlılık seviyelerinde yaşanan azalmalar ve sonucunda da sektörde birçok şirketin zararla karşılaşmasına neden olabilecektir. Bu kapsamda sektör genelinde araştırmaların arttılması, üçer aylık veya daha kısa dönemli veriler üzerinden incelemelerin yapılması önerilmektedir.

Benzer şekilde yapılan diğer araştırmalar da incelendiğinde, bankaların sigorta işlemleriyle ilgili pek bir bilgiye ulaşılamadığı görülmüştür. Bankaların sigorta işlemi yapmalarının bankanın etkinliğini, karlılığını nasıl etkilediği yönünde bir çalışmaya rastlanmamıştır. Dağıtım kanalları içindeki payının incelenen 16 yıl içinde arttığı hatırlanırsa, bu tür araştırmaların yapılması son derece önem kazanmaktadır.

Ayrıca, Türkiye'de sigorta sektörü gelişmekte olan bir sektör olduğundan dolayı şirketlerin geçmiş dönemlerine yönelik bilanço verilerine ve prim üretimi veya teminat tutarları gibi bilgilerine ulaşma olanağı kısıtlı olabilmektedir. Örneğin Türk Sigorta Birliği tarafından yayınlanan prim üretimi verilerinde en fazla 2006 yılına kadar olan döneme dair veriler yer almaktadır. Ayrıca sektör sürekli olarak yasal düzenlemeler ile geliştirilmektedir. Bu durum da sektörün birtakım bilanço kalemlerinde tanım ve isim değişikliklerine neden olmakta ve geçmiş yıllarla ilgili olarak araştırılan verilerin bilanço kalemlerindeki isim ya da hesaplama farkl11ıklarından kaynaklanan veri kayıplarına yol açabilmektedir. $\mathrm{Bu}$ nedenle sektör genelinde yapılan yasal düzenlemelerin veri kaybını ve hesaplama farklılıklarını en aza indirecek şekilde yapılması sektör için hayati önem taşımaktadır. 


\section{Kaynaklar}

Altan, Mitra S. (2010), “Türk Sigortacıllk Sektöründe Etkinlik: Veri Zarflama Analizi Yöntemi ile Bir Uygulama”, Gazi Üniversitesi İktisadi ve İdari Bilimler Fakültesi Dergisi, C:12, S:1, ss.185-204.

Ayhan, Cansu (2017), Türkiye'deki Sigortacllık Sektörünün Etkinlik Analizi ve AB Ülkeleri ile Karşılaştırılması, Yayınlanmış Yüksek Lisans Tezi, Pamukkale Üniversitesi Sosyal Bilimler Enstitüsü, Denizli.

Atan, Murat (2005), “Üretim ve Verimlilik Artırma Teknikleri”, Ankara Üniversitesi Ikktisadi İdari Bilimler Fakültesi Eğitim Notları, Ankara.

Barros, C.P., Barrosso, N., Borges, M.R. (2005), "Evaluating the Efficiency and Productivity of Insurance Companies with a Malmquist Index: A Case Study for Portuqal", The Geneva Papers on Risk and Insurance: Issues and Practice, Vol. 30, No. 2, pp. 244-267.

Boussofiane, A., Dyson R.G., Thanassoulis, E. (1991), “Applied Data Envelopment Analysis”, European Journal of Operational Research, Vol:52, Issue:1, pp.1-15.

Cook, W.W. ve Seiford, L.M. (2009), "Data Envelopment Analysis (DEA) - Thirty Years on" European Journal of Operational Research, Vol:192, Issue:1, pp.1-17.

Cooper, Wade. W., Seiford, Lawrence M., Tone, Kauru (2000), Data Envelopment Analysis A Comprehensive Text with Models, Applications, References and DEA-Solver Software, Kluwer Academic Publishers: United States.

Cooper, William W., Seiford, Lawrence M., Tone, Kaoru (2007), Data Envelopment Analysis: A Comprehensive Text with Models, Applications, References and DEA-Solver Software, 2. Edition, Springer: New York, United States.

Charnes, A., Cooper W.W., Rhodes E. (1978), "Measuring the Effiency of Decision Making Units", European Journal of Operational Research, Vol:2, pp.429-444.

Charnes, A., Cooper, W., Lewin A.Y. (1994), Data Envelopment Analysis Theory, Methodology and Applications, Kluwer Academic Publishers: London.

Cooper, William W., Seiford, Lawrence M., Zhu, Joe (2004), Handbook on Data Envelopment Analysis, Kluwer Academic: Boston.

Cummins, J.D., Weiss, M.A. (1993) "Measuring Cost-Efficiency in Property-Liability Insurance Industry", Journal of Banking and Finance, Vol:17, pp.463-481.

Cummins, J.D., Turchetti, G. and Weiss, M.A. (1996) "Productivity and Technical Efficiency Italian Insurance Industry", Whartoon School Financial Institutions Center Working Paper, Vol:96-10.

Cummins, J.D., Zi, H. (1996) "Measuring cost efficiency in the U.S. life insurance industry: Econometric and mathematical programming approach" The Warton Financial Institution Center, pp.1-43.

Cummins, J.D., Tennyson, S., Weiss, M.A. (1998) "Consolidation and Efficiency in the U.S. Life Insurance Industry", Journal of Banking and Finance, Vol:23, pp.325-357.

Çakmak, Deniz, (2019), Türk Sigortacllk Sektörünün Etkinlik Analizi ve Ekonomik Büyümeye Etkisi, Yayınlanmamış Yüksek Lisans Tezi, Bilecik Şeyh Edebali Üniversitesi, Sosyal Bilimler Enstitüsü.

Depren, Özer (2008), Veri Zarflama Analizi ve Bir Uygulama, Yayınlanmamış Yüksek Lisans Tezi, Yıldız Teknik Üniversitesi Fen Bilimleri Enstitüsü, İstanbul.

Donthu, Naveen ve Yoo, Boonghee (1998), "Cultral Influences on Service Quality Expectations", http://dx.doi.org/10.5539/ass.v11n25p151, Journal of Service Research, Vol:1, Issue:2, pp.178-186.

Eling, M.\&Luhnen, M. (2009), "Efficiency in the international insurance industry: A cross-country comparison", Journal of Banking \& Finance, http://www.uniulm.de/fileadmin/website_uni_ulm/mawi.inst.140/Articles/Eling/Eling_Luhnen_JBF_2.

Forsund, F.R. ve Sarafoglou, N. (2002), "On the Origins of Data Envelopment Analysis", Journal of Productivity Analysis, Vol:17, Issue:1-2, pp.23-40.

Gardner, L.A., Grace M.F. (1993), "X-Efficiency in the U.S. Life Insurance Industry", Journal of Banking and Finance, Vol:17, pp.497-510.

Greene, W.H., Segal, D. (2004), "Profitability and Efficiency in the U.S. Life Insurance Industry", Journal of Productivity Analysis, Vol:21, pp.229-247. 
Hazine ve Maliye Bakanlığı, Sigortacılık ve Bireysel Emeklilik Sistemi Faaliyet Raporları. [Erişim: 12.09.2018, https://www.hmb.gov.tr/sigortacilik-ve-ozel-emeklilik-raporlari].

Horasan, Esra (2013), Türkiye'de Sigorta Şirketlerinin Kurumsal Yatırımcı Olarak Finansal Piyasalardaki Etkinliğinin Veri Zarflama Analizi ile Ölçümü, Yayınlanmamış Yüksek Lisans Tezi, Atatürk Üniversitesi Sosyal Bilimler Enstitüsü, Erzurum.

İnan, E. Alpan (2000), "Banka Etkinliğinin Ölçülmesi ve Düşük Enflasyon Sürecinde Bankacılıkta Etkinlik", Bankacllar Dergisi, S:34, ss.82-96.

Jamett1 M., Ungern T.V. (2003), "Assessing the Efficiency of an Insurance Provider- A Measurement Error Approach”, https://ssrn.com/abstract=400161, CESIFO Working Paper Vol: 928, Issue:9.

Kahya, Mehmet (2001), Sigorta ve Reasürans Şirketlerinde Finansal Analiz, Sentez Reklam ve Danışmanlık Yayınları: İstanbul.

Kayal1, Cevdet (2007), “2000-2006 Döneminde Türkiye'de Faaliyet Gösteren Sigorta Şirketlerinin Etkinlik Değerlendirmesi”, Celal Bayar Üniversitesi İktisadi ve İdari bilimler Fakültesi Dergisi, C:14, S:2, ss.13-115.

Kılıçkaplan, S. ve Karpat, G. (2004), “Türkiye Hayat Sigortası Sektöründe Etkinliğin İncelenmesi”, Dokuz Eylül Üniversitesi Íktisadi ve İdari Bilimler Fakültesi Dergisi, C:19, S:1, ss.1-14.

Kılıçkaplan, S. ve Baştürk, F. H. (2004), “Türkiye'de Hayat-dışı Alanda Faaliyet Gösteren Sigorta Şirketlerinin 2002 Yılındaki Etkinliklerinin Veri Zarflama Analizi (VZA) ile Ölçülmesi”, Gazi Üniversitesi İktisadi ve İdari Bilimler Fakültesi Dergisi, C:6, S:2, ss.63-79.

Kılınç, Fatma E. (2009), Türk Sigortacılık Sektörünün Veri Zarflama Analizi Yöntemi ile Etkinliğinin Araştırılması Tezi, Yayınlanmamış Yüksek Lisans Tezi, Süleyman Demirel Üniversitesi Sosyal Bilimler Enstitüsü, Isparta.

Kırer, Hale (2007), Veri Zarflama Analizi ve Sigorta Sektörü Üzerine Bir Uygulama", Yayınlanmamış Yüksek Lisans Tezi, Marmara Üniversitesi Sosyal Bilimler Enstitüsü, İstanbul.

Liu, T. (1994) "Evaluation Operating Efficiency of Life Insurance Industry in Taiwan: A Comparison of Local and Foreign Companies", Journal of Insurance, Vol:2, pp.114-126.

Özbek, Sinem (2007), Sigorta Şirketlerinin Etkinliğinin Veri Zarflama Analizi ile İncelenmesi, Yayınlanmamış Yüksek Lisans Tezi, Marmara Üniversitesi Sosyal Bilimler Enstitüsü, İstanbul.

Özcan, Anıl İ. (2011), “Türkiye'de Hayat D1şı Sigorta Sektörünün 2002-2009 Dönemi İtibariyle Etkinlik Analizi”, Celal Bayar Üniversitesi Sosyal Bilimler Dergisi, C:9, S:1, ss:61-78.

Ramanathan, R. (2003), An Introduction to Data Envelopment Analysis: A Tool for Performance Measurement, Sage Publications: New Delhi.

Rai, Anoop (1996), “Cost Efficiency of International Insurance Firms”, Journal of Financial Services Research, Vol:10 pp.213-233.

Thanassoulis, Emmanuel (2003), Introduction to the Theory and Application of Data Envelopment Analysis, Kluwer Academic Publishers: United Kingdom.

Tezergil, Seher (2018), "Veri Zarflama Analizi ile Türk Sigorta Sektörünün Elementer Branşlarda Değerlendirilmesi”, Journal Business Research Turk, C:9, S:4, ss.342-357.

Turgutlu, E., Kök, R., Kasman, A.(2004), “Türk Sigortacılık Şirketlerinde Etkinlik: Deterministik ve Şans Kısıtlı Veri Zarflama Analizi”, Dokuz Eylül Üniversitesi, İzmir.

Yuengert, Andrew M. (1993) "The Measurement of Efficiency in Life Insurance: Estimates of a Mixed NormalGamma Error Model”, Journal of Banking and Finance, Vol:17, pp.483-496.

Yücel, Leyla İ. (2017), Veri Zarflama Analizi, Der Yayınları: İstanbul. 